\title{
Reevaluating the Co-Management Success Story
}

\author{
PAUL NADASDY ${ }^{1}$
}

(Received 5 December 2002; accepted in revised form 8 May 2003)

\begin{abstract}
The integration of science and traditional knowledge (TEK), a cornerstone of contemporary cooperative management, entails translating First Nation people's life experiences into forms compatible with state wildlife management (e.g., numbers and lines on maps), with all the risks of distortion inherent in any translation process. Even after such a translation, however, knowledge-integration remains fraught with difficulties, many of which seem on the surface to be technical or methodological. Surprisingly, despite these difficulties, the literature is full of accounts of successful co-management. I call for a more critical and nuanced analysis of co-management, one that takes different perspectives into account and calls into question what we mean by "success" in the first place. To this end, I examine the case of the Ruby Range Sheep Steering Committee (RRSSC), a co-management body in the southwest Yukon that some have held up as a model of success. Over the course of three years, RRSSC members gathered information about Dall sheep (Ovis dalli dalli) from many sources and managed to express it all in forms compatible with scientific wildlife management. Yet, even then-with a single exception-RRSSC members failed to integrate their knowledge about sheep. Although there were numerous technical and methodological obstacles to knowledgeintegration, the underlying reasons for this failure were ultimately political. Thus, a focus on the political dimensions of knowledge-integration is essential to an understanding and assessment of co-management.
\end{abstract}

Key words: traditional knowledge, cooperative management, space, time, trust, power, Dall sheep, wildlife, First Nations, Yukon

RÉSUMÉ. L'intégration de la science et du savoir écologique traditionnel (SET), une pierre angulaire de la cogestion pratiquée de nos jours, nécessite que soit traduit le vécu des gens des Premières nations sous des formes compatibles avec la gestion gouvernementale de la faune (p. ex., chiffres et lignes sur les cartes), avec les risques de distorsion inhérents à toute opération traduisante. Mais même après une telle traduction, l'intégration du savoir reste truffée de difficultés, dont un grand nombre semble être de prime abord d'ordre technique ou méthodologique. Curieusement, malgré ces difficultés, la documentation regorge de témoignages de cogestion réussie. Je réclame une analyse plus critique et plus nuancée de la cogestion, une analyse qui tienne compte de différents points de vue et remette en question ce que l'on entend tout d'abord par «réussite». À cette fin, j'examine le cas du Comité directeur du mouflon de Ruby Range (RRSSC), organisme de cogestion situé dans le sud-ouest du Yukon et qui est cité par certains comme un modèle de réussite. Au cours d'une durée de trois ans, les membres du RRSSC ont collecté de l'information sur le mouflon de Dall (Ovis dalli dalli) auprès de sources multiples et ils sont parvenus à l'exprimer entièrement sous des formes compatibles avec la gestion scientifique de la faune. Pourtant, même là - à une exception près -, les membres du RRSSC ne sont pas arrivés à intégrer leur savoir sur le mouflon. Bien qu'il y ait eu de nombreux obstacles techniques et méthodologiques à l'intégration du savoir, les raisons sous-jacentes à cet échec étaient en fin de compte politiques. Pour comprendre et évaluer la cogestion, il est donc essentiel de se concentrer sur les dimensions politiques de l'intégration du savoir.

Mots clés: savoir écologique traditionnel, cogestion, espace, temps, confiance, pouvoir, mouflon de Dall, faune, Premières nations, Yukon

Traduit pour la revue Arctic par Nésida Loyer.

\section{INTRODUCTION}

In recent decades, biologists and aboriginal people across the North have begun cooperating with one another to manage northern wildlife populations. Such efforts have intensified to the point that today cooperative management (or co-management) has become the norm. A wide variety of co-management regimes and programs are currently in place throughout the North American Arctic and Subarctic. A cornerstone of co-management is the recognition on the part of biologists and scientific resource managers of the existence of traditional ecological knowledge (TEK) and its potential value in the management process, and a primary goal of co-management has been to gather this TEK from the aboriginal elders and hunters who hold it and to integrate it with the scientific knowledge produced by biologists and other scientists.

The proliferation of co-management policies and initiatives has been accompanied by a burgeoning literature, both academic and policy-oriented. Although some of this

\footnotetext{
${ }^{1}$ Department of Anthropology, University of Wisconsin - Madison, 1180 Observatory Dr., Madison, Wisconsin 53706, U.S.A.; penadasdy@wisc.edu

(C) The Arctic Institute of North America
} 
literature examines the phenomenon of co-management in general or theoretical terms, much of it consists of case studies that assess particular instances of co-management (e.g., Williams and Hunn, 1982; Freeman and Carbyn, 1988; Johannes, 1989; Inglis, 1993; many more examples can be found in the "gray literature" of government reports). Such case studies have also constituted the majority of the presentations at every co-management conference and symposium I have attended in the North (e.g., Roberts, 1996; Urquhart, 2001). Even a cursory perusal of this literature reveals a striking fact: virtually every co-management case study encountered in the literature is a success story. The authors of these studies portray the comanagement processes they studied in a positive light, giving the impression that, although we still have much to learn, the use of TEK and its integration with science have already significantly improved the practice of wildlife management in the North and have helped to give aboriginal people more control over local land and resources. A more thorough examination of the literature bears out this initial impression; indeed, I have yet to come across a single account of failed co-management in the North. It is true that many studies identify technical problems with the design and implementation of various co-management processes. However, while they argue that these problems can detract somewhat from the effectiveness of the comanagement process under scrutiny, they tend to view such problems neither as insurmountable nor as invalidating the overall process.

A few scholars who have critically examined the project of knowledge-integration and its underlying assumptions (e.g., Cruikshank, 1998; Fienup-Riordan, 1998; Nadasdy, 1999) offer theoretical critiques of the general process, but no one presents a detailed study of a particular case of comanagement that failed. And such critiques stand in striking contrast to the many successful case studies that comprise the bulk of the TEK literature. One might reasonably point to all those case studies and declare that comanagement seems to be proceeding quite smoothly, despite the theoretical objections raised by a few critics. But the very lack of documented failures in the co-management literature is in itself suspicious.

In the first place, everyone, scholars, government officials, and aboriginal people alike, agrees that the crosscultural negotiations involved in co-management and knowledge-integration are exceedingly difficult and complex. It therefore seems highly improbable that every single effort at co-management to date could have met with success. Second, one need only listen to the coffeebreak conversations between official presentations at comanagement conferences to know that not everyone agrees with the glowing "official" assessments of co-management practice. On numerous occasions at such conferences, I have heard aboriginal people (who were involved in the very same co-management processes that were the subjects of positive presentations by government resource managers) complaining that things hadn't worked out quite the way government managers presented them. Finally, I am suspicious of the entire "co-management success story" genre, in large part because of my own experiences with a particular process of co-management: that of the Ruby Range Sheep Steering Committee (RRSSC), an ad hoc co-management body created in 1995 to address concerns about declines in a population of Dall sheep (Ovis dalli dalli) in the southwest Yukon.

It would be difficult to maintain the position that the RRSSC process was a success. On the contrary, it was, in many ways, a dismal failure, although not everyone involved in the process would agree with that assessment. Indeed, one of the most striking things about the RRSSC process is how differently various members of the committee perceived and evaluated what took place over the nearly three years during which they met to formulate management recommendations. Some RRSSC members (mostly government scientists and resource managers) came away from the process feeling that it had been a success. Indeed, I heard several biologists who had been on the committee describe the process in glowing terms, holding it up as a model of co-management to be emulated elsewhere in the territory. However, other committee members, mostly First Nation people, felt that it had been a complete failure (and worse, that government biologists had betrayed them).

In this article, I examine certain aspects of the RRSSC process with an eye to understanding how members of the RRSSC could have perceived the process so differently from one another. I make no claims that my critique of the RRSSC can be generalized and applied to all processes of co-management, but some of the patterns and dynamics I describe are widespread and general enough to suggest that similar criticisms might be applied to other co-management processes as well. My goal here is not to make general statements of co-management writ large, but to cultivate a healthy skepticism of the "co-management success story" and call for more critical and nuanced analyses of particular co-management processes, analyses that call into question how we might go about evaluating such processes.

Finally, it is not my intention here to pass judgment on any of those who participated in the RRSSC process. On the contrary, I believe that nearly everyone involved participated in good faith, sincerely hoping to work together to solve a common problem in an atmosphere of trust, respect, and cooperation. Rather, I am critical of the process itself and seek to understand the social interactions between members of the RRSSC in light of the unexamined assumptions that they brought to the table and the larger political context of sheep management in the territory.

\section{THE CASE OF THE MISSING SHEEP}

Elsewhere (Nadasdy, 1999), I have examined the political consequences of the effort to integrate TEK and science 
for purposes of co-management. I argued that since the project of knowledge-integration assumes that the utility of TEK lies in its incorporation into existing structures of state resource management, TEK researchers necessarily treat TEK as simply a new form of "data" to be incorporated into existing management bureaucracies and acted upon by scientists and resource managers (see also Cruikshank, 1998). This necessitates the translation (and distortion) of First Nation people's beliefs, values, social relations, and practices into forms (e.g., numbers and lines on maps) that are more compatible with bureaucratic resource management than with the lives of First Nation elders and hunters. Further, I argued that TEK researchers' preoccupation with technical and methodological obstacles to knowledge-integration have obscured the power relations that underlie the whole process of knowledgeintegration and co-management. The supposedly technical process of translation takes the very institutions and practices of bureaucratic management as givens (see also Nadasdy, in press). Because of this, the process of knowledge-integration and co-management ends up taking for granted existing aboriginal-state relations and perpetuating (rather than transforming) unequal power relations.

Here, however, I examine the next stage of the comanagement process: that which follows the translation of First Nation experiences into TEK. After all, despite everything that is lost and transformed in the process of translating First Nation people's lived experiences into numbers and lines on maps, something survives. The numerical and graphic understandings sought by biologists are not completely foreign to the experiences of First Nation people. Elders and hunters often possess detailed knowledge about animals (how many, when, and where) that can be expressed in forms that are entirely compatible with those regularly used by biologists. These numbers and lines on maps, however decontextualized they may be, are nevertheless rooted in First Nation elders' and hunters' experiences on the land. Thus, some might argue that integrating these numbers with the knowledge of biologists should still be of some benefit despite the problems inherent in the translation process. And, precisely because these numbers and lines on maps have been decontextualized, this integration should be fairly straightforward. Yet, even after First Nation people and biologists have agreed on the numbers and what they mean, knowledge-integration remains fraught with difficulties. Many of these obstacles to integration appear to be technical or methodological in nature. Just as in the case of gathering and translating TEK, however, it would be a mistake to focus solely on the technical dimensions of this stage of knowledge-integration. To do so would ignore the political context in which it takes place and take for granted existing political inequalities.

RRSSC members did indeed face technical and methodological obstacles in their attempts to gather and integrate different ways of knowing about sheep. Over the course of nearly three years, however, they intentionally worked to overcome these obstacles. They gathered information about Dall sheep from various sources, including First Nation elders and hunters, outfitters, and biologists, and successfully managed to express it all in a form compatible with scientific wildlife management practice (see Nadasdy, 2003: chap. 4). As I have noted elsewhere (Nadasdy, 1999, 2003: chap. 5), this process was itself far from politically neutral. Yet, by rendering the information gathered from these disparate sources into forms that were compatible with one another, RRSSC members did set the stage for their integration. Even then, however, with a single exception, they failed to do so. To understand why, it will be helpful to look at the one case of successful knowledge-integration that did occur. An examination of this instance provides insights into why such integration did not occur more often.

In July 1996, Yukon government biologists conducting an aerial survey of the Ruby Range in the southwest Yukon counted 147 fewer Dall sheep than they had just the year before-an apparent decline of almost $26 \%$ in the course of a single year. This drop in the population was potentially of serious concern to the members of the RRSSC. When biologists presented their results to the committee on 28 January 1997, however, no alarms were sounded. Indeed, by that time, they were confident that the sheep population had not in fact declined at all. Significantly, the biologists had not come to this conclusion on their own; instead, they had come to their current knowledge of the sheep population by integrating their own knowledge (the product of aerial surveys and other techniques of scientific wildlife management) with the very different knowledge of another member of the RRSSC.

Any attempt to understand why the biologists were not worried about the sheep population must begin with a look at the unusual circumstances surrounding the aerial survey itself. For one thing, biologists performed the 1996 annual survey in July rather than in June, when it was normally conducted. The second unusual circumstance was that there was still significant snow cover in the mountains when the survey was carried out, making it harder to spot the white Dall sheep from the air. The biologists later confessed that these factors had caused them to mistrust the results of their survey and suspect they were not comparable to the survey data from previous years. Fortunately, the big game outfitter in the area, also a member of the RRSSC, conducted his own sheep count during the autumn 1996 hunting season. Eight hunting guides working for him counted the sheep in his outfitting area and obtained results very similar to those of the Yukon government's aerial survey-except in one game management subzone, where they counted approximately 100 more sheep than had been counted in the helicopter survey. What is more, they counted all of those 100 sheep in an area where the aerial survey had found no sheep at all. After the hunting season, the biologists and the outfitter met to compare data. Together they decided that the helicopter survey must have missed those 100 sheep because 
they were outside the study area in July, though they had returned to it by the start of the hunting season a few weeks later. They jointly concluded that the drop in the sheep count represented problems with the survey (different time of year, snow cover, and 100 moving sheep) rather than a drop in the actual number of sheep. So, by the time they presented the survey results to the other RRSSC members in January 1997, biologists felt confident that it was their survey data, rather than the sheep population, that had a problem.

This tale of the 100 missing sheep should be heartwarming to proponents of co-management. It is a perfect example of the kind of "knowledge-integration" that is supposed to be the centerpiece of co-management practice. By integrating the outfitter's local, land-based knowledge with the scientific knowledge generated by biologists, these RRSSC members had improved everyone's overall knowledge of the sheep; and by working together in this way, biologists and outfitter had helped to build trust and a cooperative relationship among (at least certain) members of the RRSSC. That this occurred should not be particularly surprising. After all, knowledge-integration of this sort is integral to the very idea of co-management. Aware of the limitations of wildlife biology and other management sciences, biologists and scientific resource managers have increasingly come to recognize the value of traditional/local knowledge not only as a corrective to the knowledge they generate, but also to fill in the temporal and geographical gaps in that knowledge. This was certainly one of the goals underlying the creation of the RRSSC in the first place.

As it turns out, there were numerous instances over the course of the RRSSC process in which committee members might profitably have worked together to integrate their knowledge of Dall sheep in precisely this way. Unfortunately, the case described above was virtually the only significant instance of knowledge-integration that occurred during the entire RRSSC process, a process that involved not only Yukon biologists and outfitters, but also First Nation people, federal government officials, and members of interested environmental organizations. Why, if everyone involved in the RRSSC process endorsed the idea of knowledge-integration (and they did), was there only a single instance in which they actually achieved it? And is it significant that the one successful case of knowledge-integration involved biologists and an outfitter-and not First Nation people? To answer these questions, we must begin by examining those methodological obstacles to knowledge-integration that remained even after the translation process. We can then ask how and why these obstacles were overcome in one case, but not others. This inquiry will ultimately lead us away from issues of technique and methodology to questions of power. I begin, however, with a very brief background discussion of the RRSSC and the politics of sheep hunting in the Yukon (for a more complete discussion of the context in which the RRSSC operated, see Nadasdy 2003: chap. 4).

\section{THE RUBY RANGE SHEEP STEERING COMMITTEE AND THE POLITICS OF SHEEP IN THE YUKON}

In the fall of 1995, the Kluane First Nation (KFN) hosted a meeting in the village of Burwash Landing, Yukon, to express their concerns about declining populations of Dall sheep in the region. This meeting led directly to the creation of the Ruby Range Sheep Steering Committee. Participants at the meeting selected RRSSC representatives from a wide range of groups with interests in Ruby Range sheep, including local First Nations, the territorial government (Department of Renewable Resources), the federal government (Parks Canada and the Department of Indian Affairs and Northern Development), local big game outfitters, and interested environmental organizations (the Yukon Conservation Society and the Canadian Parks and Wilderness Society). The RRSSC was to make management recommendations regarding Ruby Range sheep to the Yukon Fish and Wildlife Management Board, a body established under the 1993 Yukon Umbrella Final Agreement as the "primary instrument of fish and wildlife management" in the territory (Council for Yukon Indians, 1993:166). To this end, the committee met several times over the next three years.

It became apparent over the course of these meetings that different participants in the RRSSC had radically different ideas about the magnitude of the decline in the sheep population, the reasons for this decline, and potential management solutions. Biologists and outfitters sitting on the RRSSC saw the population decline as relatively minor, a temporary fluctuation caused by several years of unusually bad weather, possibly exacerbated by predation (from wolves and coyotes) and harassment from lowflying aircraft and all-terrain vehicles. Significantly, neither biologists nor outfitters felt that hunting by humans had contributed to the sheep decline. Ultimately, they felt that the sheep population would recover on its own, but they were willing to support management initiatives that addressed the issues of predation and harassment to help speed the population's recovery. Both opposed any restrictions on hunting, the outfitters adamantly so.

By contrast, Kluane First Nation members of the RRSSC saw the decline in the sheep population as long-term and catastrophic. They argued that the population had been declining steadily since the 1960 s and that the situation had now reached crisis proportions. They agreed with biologists and outfitters that predation and harassment were factors in the decline, but they vehemently disagreed with them about the role of weather and human hunting. Sheep, they felt, were quite accustomed to Yukon weather, and, in any case, a few bad years could not explain a longterm decline of the sort they had seen. Some elders and hunters even found the suggestion that weather caused the decline to be disrespectful to the sheep, implying that they were too stupid to take care of themselves in their own homeland. The biggest point of contention between Kluane people on the one hand and outfitters and biologists on the 
other was over the significance of human hunting. Kluane people identified hunting, especially by outfitters, as the single most important factor leading to the decline of the sheep population. They advocated a total ban on sheep hunting in the region or, failing that, a quota on the number of sheep that could be taken.

RRSSC members' different positions regarding the nature of the decline in sheep and its possible remedies arose, at least in part, from the different ways in which each experienced and came to know about sheep in the first place. Wildlife biologists, for example, generated knowledge about sheep primarily through a number of formal activities (i.e., "research"), the most important of which was an aerial survey conducted by helicopter. The results of this research were then disseminated in the form of written reports and scientific papers. In contrast, First Nation elders and hunters based their understandings of sheep on personal experiences gained over many years spent out on the land while hunting, trapping, fishing, guiding, and traveling. They shared these experiences and the lessons they drew from them orally, in the form of stories, rather than in written form. As we shall see, these differences led RRSSC members to have very different understandings about Ruby Range sheep. At an even more fundamental level, committee members disagreed (at least implicitly) on what constituted valid knowledge about sheep in the first place, and even on the nature of the sheep themselves (for a more comprehensive discussion of the different ways in which different RRSSC members produced knowledge about sheep, see Nadasdy, 2003: chap. 4).

The disagreement between First Nation people, on the one hand, and biologists and outfitters, on the other, also had obvious political dimensions. Dall rams, with their large curving horns, are a prized trophy animal for big game hunters all over the world. As trophy animals, Dall sheep represent a significant potential income for big game outfitters, who charge hunters substantial sums for their hunts, as well as for the territorial government, which sells hunting licenses and collects trophy fees and taxes. At the same time, Dall sheep have been an important part of the diet of First Nation people in the southwest Yukon for at least the last 2000 years (see McClellan, 1975:120, and Arthurs, 1995, for historical and archeological evidence of sheep hunting, respectively). Kluane people continue to think of themselves as sheep hunters. They speak highly of the virtues of sheep meat and occasionally have gone to great lengths to get it. I was told one story, from the days before the restoration of KFN people's hunting rights in the neighboring Kluane National Park and Game Sanctuary, in which a man risked fines and imprisonment to get sheep for his father's funeral potlatch, because he felt that a proper ceremony could not be held without sheep meat. I also heard countless stories about specific sheep hunts, some of which had occurred as far back as the turn of the century (see McClellan, 1975:121-122 for accounts of mythic stories and ritual behavior associated with sheep). Kluane people have detailed knowledge of where to go to hunt sheep and can locate dozens of traditional sheep hunting camps throughout their territory, many of which are in the Ruby Range. Finally, on several occasions, I heard Kluane people specifically use their self-ascribed status as sheep hunters to contrast themselves to members of a neighboring First Nation, whom they claimed did not traditionally rely on sheep for subsistence. Despite the importance of sheep hunting to Kluane people, however, KFN members claimed that they had refrained completely from hunting sheep in the Ruby Range for several years prior to the formation of the RRSSC, out of concern for the sheep population.

Struggles between those who see animals as trophies and those who see them as food have historically played an important role in characterizing the politics of big game hunting in the Yukon (see McCandless, 1985; n.d.). In the case of sheep, the struggle is especially intense. It is so intense that, despite overwhelming archaeological and oral evidence, it was not until 1998 (after the RRSSC process had ended) that the territorial government at last formally acknowledged that Dall sheep should be classified as a traditional subsistence animal under the KFN's land-claim agreement. Until that time, the government had refused to include sheep with moose and caribou as animals to which First Nation people had special rights in the event of the need to establish a Total Allowable Harvest as per 16.9.0 of the Yukon Final Agreement (Council for Yukon Indians, 1993:176-177). Despite the intensity of the struggle over sheep in the region, outfitters and First Nation people, the two most important groups involved in the struggle, have very different degrees of access to state power. Although First Nation people's political presence in the territory has increased dramatically over the past 30 years, there remains a wide gulf between First Nation communities and the halls of power in Whitehorse. Big game outfitters, on the other hand, have historically had considerable influence in the territorial government. That influence is due at least in part to the financial benefits that accrue to the Yukon Government from outfitting, but other factors also contribute to the outfitters' political clout. For one thing, outfitting is an old and respected (not to mention colorful) tradition in the Yukon, and today's outfitters, as practitioners of that tradition, can draw on powerful historical imagery to justify their positions. Another source of outfitter strength is their political organization. Though there are only 20 outfitters in the Yukon, they present a common front through the actions of the well-organized and very active Yukon Outfitter's Association, a political force to be reckoned with in the territory. Perhaps the greatest source of their political strength, however, is their membership in an elite stratum of Yukon society. Business and government in the territory are dominated by a relatively small number of businessmen who are long-time Yukoners, and outfitters have traditionally been among the members of this group. In 1995, for example, when the RRSSC was formed, at least two members of the Yukon Legislative Assembly-one of whom was the government leader-were ex-outfitters. 
Because of the outfitters' political power, it would have been difficult for the Yukon Department of Renewable Resources to implement any management initiatives opposed by outfitters (e.g., a ban on hunting), regardless of RRSSC recommendations. This is not to say that it would have been impossible, but at the very least, wildlife managers would have had to produce evidence convincing to Yukon politicians to support such action. And, despite rhetoric about the value of TEK, this still means evidence produced by biologists, not the uncorroborated testimony of First Nation elders-especially if that testimony contradicts the biological evidence.

Such was the political context into which the RRSSC was born. As discussed above, an important part of the RRSSC process was to translate First Nation elders' and hunters' understandings (and indeed all RRSSC members' understandings) into a form compatible with the reports and published papers of wildlife biologists (i.e., written text, numbers, lines on maps). Integration of these knowledge artifacts remained far from straightforward, however, despite their common form. Many of the obstacles to integration appeared to be technical or methodological. Sheep move around, and population sizes fluctuate over time. Everyone's understanding of sheep, then, is necessarily based on where, when, and how each person observed or interacted with them. Thus, it was often extremely difficult to compare one RRSSC member's knowledge of Ruby Range sheep with another's, even after they had been translated into a form compatible with scientific wildlife management. I turn now to an examination of these methodological obstacles to knowledge-integration, not because they prevented knowledge-integration, but because-in one case-they did not.

\section{TIME, SPACE, AND THE INTEGRATION OF KNOWLEDGE}

\section{Time}

The temporal dimension is vital to the practice of wildlife management. Time structures what and how people know about animal populations. Temporal differences in what RRSSC members knew about Ruby Range sheep provided an incentive for knowledge-integration, but at the same time, acted as an obstacle. Temporal differences existed on a number of different levels, from the length of time (in years) that various RRSSC members had been observing sheep in the Ruby Range to the time of year when they made these observations. All of these differences played a role in the dynamics of co-management in the RRSSC.

To manage wildlife effectively, one must have good long-term knowledge of wildlife populations. One must know how these populations are changing, why they are changing, and what can be done to effect desired changes. Especially important for management is an understanding of the impact of human activity on animal populations. Since even "stable" wildlife populations experience significant fluctuation from year to year, however, it can often be very difficult to determine the causes-or even the significance-of changes in population size. In an ideal situation, in which biologists have good long-term data from a population in a fairly natural state, they might feel confident in their ability to distinguish the effects of human activity from the stochastic fluctuations experienced by wildlife populations in the absence of humans.

Unfortunately, such long-term scientific data on animal populations do not exist in the North, where wildlife biology is a relatively recent arrival. The Yukon Government, for example, did not hire a wildlife biologist until 1974, the year of the first Ruby Range sheep survey. This problem is further compounded by the expense of conducting wildlife surveys, which has made it impossible for biologists to carry out regular surveys of animal populations in all but a few relatively small areas, even since their arrival in 1974. As biologists themselves admit, this constitutes a serious limitation to their knowledge of wildlife in the territory, often making it difficult for them to assess the effects of human activity on wildlife populations. To make up for their lack of temporal data on animal populations, biologists focus on maximizing the data obtained from animals taken by hunters and make comparisons between different (spatially separate) populations of the same species.

Ruby Range sheep are exceptional among Yukon wildlife populations for the amount and time-depth of the data that have been collected about them. Biologists first surveyed Ruby Range sheep in 1974 and have been doing so relatively consistently since 1979 . Thus, they are better able to assess the impact of human activity on the Ruby Range sheep population than on nearly any other animal population in the Yukon. Given the history of this region, however, 20 years of data are still inadequate. Serious over-hunting occurred in parts of the territory at least as early as the Klondike gold rush in 1898. Although the population (and the pressure on wildlife) subsided somewhat in later years, the rise of the big game outfitting industry and several subsequent short-lived population booms (most notably the result of Alaska Highway construction in 1941-42) continued to put pressure on wildlife populations in the region. All of these events, especially the building of the highway, affected wildlife populations in the Kluane area, sometimes quite significantly (Hoefs, 1981; McCandless, 1985). Indeed, as Kluane elder Dick Dickson (pers. comm. 1996) put it, "You think game is scarce around here today? You should have seen it when the [Alaska] highway came through." Although biologists attempt in several ways to "factor out" human impact on these populations, their methods are necessarily based on educated guesswork.

In contrast, First Nation elders and hunters have been in the Yukon for considerably longer than 25 years. Indeed, some elders have detailed memories of the Ruby Range 
from as far back as the 1920s, and they heard stories of earlier times from their own elders. These people do not depend on costly helicopters to see sheep in the Ruby Range, nor do they have to juggle the need to survey those sheep with the need to study other wildlife populations throughout the territory, all on a single limited budget. Rather, they observe sheep in the Ruby Range as a natural part of their lives out on the land hunting and trapping. As a result, their knowledge of Ruby Range sheep has fewer temporal gaps than the biological survey data (I am speaking here of the village viewed collectively. Certainly there are gaps in specific individuals' personal experiences of the Ruby Range, but it would be difficult to find a long stretch of time during which no one in the village visited the region.)

Proponents of knowledge-integration often cite such differences in the temporal dimensions of TEK and science as a primary reason for integrating them, since the long-term observations of First Nation hunters can complement the more occasional but intensive observations made by biologists and resource managers. By integrating these two sets of information, many resource managers hope to be able to extend their knowledge of animal populations significantly into the past (Ferguson and Messier, 1997). Indeed, it is precisely to supplement their inadequate data about animal populations that many northern resource managers have begun turning to TEK.

Biologists involved in the RRSSC process explicitly acknowledged such knowledge-integration as one of the most important advantages to managing the Ruby Range sheep cooperatively; however, despite this acknowledgment and the apparent advantages of integrating hunters' perspectives on Ruby Range sheep with their own, biologists have proved unwilling or unable to incorporate First Nation hunters' accounts of past population sizes into their model of the Ruby Range population. According to every single hunter who spoke to the RRSSC, there were once many more sheep in the Ruby Range than there are today, and all agreed that the population decline began well before the first aerial survey was conducted in 1974 (and certainly before these surveys became a regular occurrence in 1979). This would seem to be an ideal situation for the temporal extension of biological data through the use of TEK. Yet this never happened.

Before RRSSC members could decide what management strategies to adopt, they had to agree on a target population to manage for. This entailed long hours of debate over what would constitute a healthy sheep population in the Ruby Range. The committee might have tried to integrate TEK and science by developing a population model based on a combination of testimony by elders and hunters and the aerial survey data (not to mention other inputs, such as those provided by outfitters). Instead, biologists and First Nation people each used their own knowledge of past sheep populations to back up their arguments over what constituted an appropriate target population. Rather than integrating what they knew about sheep, RRSSC members struggled with one another over whose knowledge they should use to set this target level.

The RRSSC finally agreed on the objective of restoring the Ruby Range sheep population to its 1980 level, the highest ever recorded by an aerial survey (RRSSC, 1996a). According to the survey data, this meant a target population of 1314 sheep for the entire study area. This figure, however, was well below First Nation expectations. Elders and hunters had been adamant that the population had once been much larger than this (indeed, they said that by 1980 the population decline was already well under way). In the end, however, they were forced to agree to this level because biologists (and outfitters) were completely unwilling to entertain the possibility of setting a higher one. Whether or not they trusted the accuracy of the First Nation testimony (and some RRSSC members clearly did not), biologists simply could not accept that testimony as a basis for action because they had no way of independently verifying that the sheep population had ever been any higher than the 1980 level. Given the sensitive political nature of sheep management, and the much greater weight accorded to scientific evidence than to First Nation testimony by the powerful interests involved, biologists needed to be able to back any recommendations with scientific evidence. As a result, biologists could not (and did not) accord the testimony of elders and hunters the same status they gave to their own survey data. It is perhaps not so surprising, then, that very little knowledge-integration actually occurred. The First Nation settled on the 1980 population as the target level because it was the highest that biologists would go, and biologists would go that high only because they themselves had counted that many sheep in the study area.

Biologists were not the only members of the RRSSC to question or undervalue other people's knowledge about sheep in the Ruby Range. First Nation people, for their part, often criticized the knowledge of biologists as part of their effort to establish their own knowledge as legitimate. They frequently contrasted biologists' (and current outfitters') status as relative newcomers to the area with their own personal and family histories. They referred to the many years that they and their parents and grandparents had hunted in the area, claiming that this wealth of experience gave them knowledge of the sheep that far surpassed any that might be gained from a dozen or so annual surveys from a helicopter. In making this argument, First Nation hunters were not simply saying that they had spent more time observing sheep than had biologists, though this was certainly part of their point. They were also commenting on the quality of those observations, claiming that over many years spent hunting out on the land, they had also learned how to observe animals. This may at first seem an odd argument to someone who has not spent any time hunting. Whenever I went out with experienced hunters, however, I was constantly impressed by their ability to spot animals. I was always the last to see them, usually after someone had pointed them out to me. And, of course, a good hunter does 
not need to see animals to know they are there. By noting tracks and other signs, he or she can get a fairly good sense of what animals are in the area, without ever actually seeing them. It became clear to me, as I spent time with these hunters, that it would take me many years of studying animals out on the land before I could hope even to approach their powers of observation. First Nation hunters are justifiably proud of their abilities in this regard; thus, elders and hunters on the RRSSC felt uniquely qualified to comment on the state of the sheep population in the Ruby Range. At the same time, they mistrusted the observations of biologists, whom they saw as lacking the very kinds of experiences they considered essential to being a good observer. As elder and hunter Frank Joe put it:

I do look at sheep when I go up the valley. Lots of time I never see any. I cover lots of country, I never see nothing. Just what we seen last year, is what I seen up in the Ruby. Head of Marshall Creek, I never seen no sheep there. My cousin went in there with Junior Moose; he saw two rams...Where I went myself, I never seen any. People say they're all around. With the plane they seen lots of sheep. When I was there I look around. I look pretty good around there. I'm used to looking for the game; I'm trained for that. Can spot a sheep or bear, anything, moose, caribou anywhere in the bush. Can spot it from here to across the lake. Sheep, I never seen any. (KFN and YTG, 1996:12)

There were other important temporal differences in RRSSC members' knowledge of sheep. Because of the vastness of the territory and the time and expense involved in conducting wildlife research, for example, biologists can at best hope to survey a given animal population once a year. In fact, even in the case of Ruby Range sheep, one of the most studied animal populations in the territory, biologists have fallen short of this modest ideal. Faced with this reality, they are careful to time their surveys so as to maximize the data they can collect. In the Ruby Range, for instance, they have traditionally flown their surveys in June, so that they could count the number of yearlings that survived the winter in addition to the number of lambs born. Also, since sheep have seasonal movement patterns, biologists must fly their annual surveys at the same time every year, or they cannot compare their results from year to year.

By contrast, although elders and hunters do not cover as much ground in a single day as biologists in a helicopter, they do see animals all year round and have a good idea of what they do and where they are throughout the entire year-not just on two days in June. In the Ruby Range, elders and hunters see sheep not only on the lambing cliffs in springtime (where biologists see them) but also in their winter and summer ranges. They watch them come down to mineral licks, note where they cross between mountain ranges, and watch them in the rut. Whereas biologists know the sheep population through a series of detailed but static and temporally isolated "snapshots," elders and hunters experience sheep more continuously through time. Rather than attempting to integrate these two different views of the lives of sheep, however, RRSSC members used them to deny the validity of one another's knowledge. First Nation people claimed that biologists' lamb counts gave an inaccurate picture of the population because of high mortality rates in the period immediately following the counts. Biologists felt that because First Nation people do not systematically count sheep at the same time every year, they do not have an adequate basis for identifying changes in the population.

\section{Space}

Like time, geography also structured how different RRSSC members viewed the problem of sheep in the Ruby Range. In fact, the different geographical dimensions of their knowledge about sheep played an important role in the very formation of the RRSSC and the creation of its mandate. As it turns out, First Nation elders and hunters did not see the decline in the sheep population as limited to the Ruby and Nisling Ranges. In fact, some elders and hunters present at the November 1995 meeting had actually spent very little time hunting in the Ruby Range. Although they were aware of the situation there, these elders and hunters were also deeply concerned about what they saw as equally severe sheep declines in other areas where they had hunted extensively. Douglas Dickson (KFN and YTG, 1996:19) described the most important such area, found to the north, between the White River and the Alaska border:

Like, White River, when I first went into that area hunting, that was 1953, I was 13 years old. I could sit on a mountain between Rabbit Creek and Boulder Creek, where Dickie [Dickson] was talking about; I'd count 600 sheep. Two deep valleys like. Twenty years later I came back there, could still count 600 sheep. A lot of time a guy could count 350 sheep in one day. I hunted [as a guide] I'd say 20 trips, and I'd get a sheep in one day. I never ever got skunked with a hunter. I'd take hunters out and I'd get game, but White River, it's just a cinch to get a sheep in one day. Now, like David [Dickson] he says, the last time I hunted up there was in 1988. He's having trouble getting sheep, the same place... Now David says he has to hunt like hell to get sheep.

Aside from two large-scale aerial surveys (in 1974 and 1993) and data on the sheep killed by non-First Nation hunters, however, biologists had very little knowledge of sheep populations in the White River area. As a result, they were unwilling to include this area in the mandate of the RRSSC. At the first meeting of the committee in December 1995, members decided that the committee would limit its activity to that area about which "both government and First Nations have some knowledge" (RRSSC, 1995:3). This decision effectively limited RRSSC activities to the 
study area used by biologists in their aerial surveys of the Ruby Range. First Nation RRSSC members were not altogether happy about this, since the study area represents just a small fraction of the area about which they were concerned, excluding not only the White River area, but also the majority of the Nisling Range. At subsequent RRSSC meetings, elders and hunters occasionally tried to extend the RRSSC's mandate beyond the Ruby Range, but to no avail.

Biologists acknowledged that the decline in sheep was not limited to the Ruby Range, stating that it was occurring in "virtually every accessible population in the territory" and into Alaska (RRSSC, 1996b:5). Indeed, they reported to the RRSSC that "Alaska reports a 40-70\% decline in almost all of their sheep populations, even in areas with little or no harvest" (YTG, 1997:7). Despite this, however, biologists were unwilling to comply with First Nation requests to expand the RRSSC's mandate into other areas of concern because "there is not enough survey information from other parts of the Yukon to know how widespread the declines are there" (YTG, 1997:7). Thus, rather than increasing their total stock of knowledge about sheep by integrating the localized knowledge of biologists with the more extensive knowledge of hunters, RRSSC members ended up struggling with one another over whose knowledge to use. First Nation people felt that biologists' knowledge about the decline in sheep was too limited geographically. Biologists, for their part, were unwilling to accept hunters' knowledge of sheep outside the Ruby Range study area as the sole basis for a management strategy in those areas.

There were other ways in which geographic differences in how RRSSC members knew sheep caused them to question the validity of one another's knowledge. The Ruby Range study area is divided into game management subzones and outfitter areas. It is also divided into several different trapline concessions and split by a boundary between two First Nation traditional territories. These arbitrary geographical divisions directly affect people's experience of the land and therefore structure their knowledge of it; yet they overlap with and otherwise fail to correspond to one another. This makes any attempt to compare different people's knowledge of the land very complex. Biologists, for example, conduct their sheep counts by game management subzone. Since these subzones do not correspond to the outfitter areas, and since outfitters count sheep in their own area, it is difficult to compare the counts of biologists with those of outfitters (one outfitter, however, did record his sheep counts by subzone. He was the same outfitter who "found" the sheep missing in the 1996 survey).

This lack of geographical correspondence becomes even more pronounced when we consider how individual First Nation elders and hunters experience the land. In the Yukon, there is no formal division of land into different hunting areas (although it is divided into different areas for trapping), but every First Nation hunter hunts and fishes in different places over the course of the year. Though different hunters may share any given place, no two hunters hunt and fish in exactly the same set of places. Thus, each hunter has what we might call a personal hunting area (which includes everywhere that a hunter goes in the bush, whether to hunt, fish, trap, pick berries, cut wood, or whatever). These personal areas may overlap, but no two are identical. Studies mapping the personal hunting areas of individual hunters in the same community (Brody, 1982) have shown that these areas vary significantly in size, shape, and location. This is certainly the case in Burwash Landing as well. Elders and hunters regularly share their observations and thoughts about the land and animals with one another, so that their knowledge of the land extends beyond their own personal hunting area. But when biologists ask them for specific information about animal sightings (e.g., sheep counts), they necessarily supply this information from their own experiences in their own unique hunting areas. This means that the testimony of individual First Nation people and the numbers that they provide to biologists may vary considerably from one person to another, especially considering the high level of geographical and temporal variation in the boreal forest (Nelson, 1983). Some biologists and resource managers misinterpret these differences among hunters as evidence for the unreliability of TEK, and this makes them suspicious of First Nation people's knowledge altogether.

One biologist told me that he had misgivings about integrating TEK and knowledge because of the "subjective" nature of TEK. He said that it was "too fluid and dependent upon individuals" to be integrated with science. Not only does TEK change over time, he said-perhaps reflecting changes in the world-but it also varies according to the hunter or elder with whom you talk. This, of course, is anathema to scientists. Scientific knowledge must be reproducible; it must be true for everyone, or it cannot be considered knowledge at all. When biologists are confronted by inconsistent and conflicting testimony by elders and hunters, some assume that this testimony is unreliable, while others recognize the complexity of the problem but are unsure how to deal with it. First Nation people and scientists alike make much of the fact that TEK is inherently local, that it is rooted in a particular place. Yet, by failing to use TEK because of differences between hunters (either because they see it as invalid or because they do not know how to use it), biologists and resource managers implicitly deny the local nature of First Nation people's experiences on the land. The fact that this knowledge is not used (even by those biologists who recognize its validity) because it does not fit easily into the practices of bureaucratic wildlife management highlights the biases inherent in the project of knowledge-integration.

This lack of geographical correspondence is further compounded when we consider its relation to the temporal differences discussed above. We saw that people's knowledge of sheep is constrained by the times when they encounter them. Biologists count the sheep population in 
the spring, while outfitters interact with sheep during the licensed hunting season (late summer and early fall). Even First Nation people's observations of sheep are necessarily time-dependent, since there are places that they visit with varying frequency or only for seasonally specific activities (like berry-picking or trapping). These temporal differences have an important geographical component, because sheep ignore the arbitrary administrative lines that humans draw on maps as they go about their seasonal movements. Thus, the timing of a sheep count can affect not only where one will see sheep, but also whether one sees them at all. For example, sheep that have their lambs outside the biologists' study area, but whose summer range in the study area overlaps an outfitter's concession, will be counted by outfitters but not by biologists. This, in fact, is precisely how one outfitter accounted for the discrepancy between his own counts and those of biologists (RRSSC, 1996b). He argued that it was inappropriate to use the biologists' aerial survey data to manage sheep hunting in his area, since spring counts did not accurately reflect the population found there during hunting season. As we have seen, however, such temporal/geographical discrepancies were not an insurmountable obstacle to knowledge-integration. In fact, biologists and outfitter subsequently overcame them and did succeed in integrating one another's knowledge to solve the problem of the sheep missing from the 1996 survey.

\section{TRUST AND THE POLITICS OF KNOWLEDGE-INTEGRATION}

Members of the RRSSC were aware of the temporal and geographical differences in one another's knowledge of sheep before the RRSSC process even began. Indeed, the existence of such differences was one of the primary incentives for engaging in co-management in the first place. The fact that different people knew about Ruby Range sheep at different times and places meant that RRSSC members could, in theory, pool their knowledge, creating a collective knowledge base that would exceed any individual's knowledge not only in quality, but also in temporal and geographical scope. At the same time, these temporal and geographical differences made it extremely difficult to compare and integrate different people's knowledge. What exactly is one to make of the differences between a June and a July sheep count, or between a count by game management subzone and one by outfitting area? What of the differences in the testimony of various First Nation hunters who have different hunting areas? There is no objective formula into which one can plug such incomparable data. If one is to make sense of these disparities, then one must engage in a process of creative interpretation. The case of the 100 missing sheep is a perfect example of such a process.

Although the biologists and outfitter had both counted sheep by game management subzone (avoiding a geo- graphical discrepancy), other differences made their counts difficult to compare. Biologists had counted sheep from the air in July, while the outfitter had counted them from the ground in August. Integrating these two counts required an act of imagination; one had to imagine the sheep leaving the area in June and returning in August. Either party could have rejected this interpretation for any number of reasons (e.g., reasons based on their understanding of sheep behavior). Even more important, biologists and outfitter had to be willing to accept and act upon the number of sheep reported by the other.

The notion of trust occupies a prominent place in the rhetoric of co-management. Government and First Nation participants in co-management processes are routinely urged to "trust one another" and warned that, without such trust, co-management cannot succeed. Certainly, biologists and outfitters had to trust one another to be truthful, to report the number of sheep they really saw. Likewise, each had to have confidence in the other's method of counting sheep. That is, they had to trust one another's ability to generate accurate data. Without these two forms of trust, they could not have integrated their knowledge as they did. But it was not enough for biologists and outfitter simply to trust one another; they also had to be willing to act on one another's information (i.e., to modify their own numbers, or at least their understanding of the meaning of those numbers, and to use those new numbers/meanings in their management efforts). This is not the same thing as trust. Indeed, the notion of trust must be viewed within the broader context of power relations. Biologists, for example, may have trusted the First Nation elders who said that the sheep population had once been much higher than it was in 1980 (i.e., they may have believed the elders to be honest and even trusted them to generate accurate sheep counts). But, given the political context of sheep hunting in the Yukon, there is no way that biologists could have accepted and acted upon First Nation elders' accounts of the size of past sheep populations. To do so would have been to endorse the view that there had been a catastrophic population decline requiring drastic and immediate action. Aside from the fact that biologists did not believe this to be the case, for them to have advocated a ban on sheep hunting (or similar drastic action) in the absence of scientific evidence to back it up would have been impossible.

Biologists on the RRSSC simply could not support a ban on hunting (or even the imposition of a quota hunt) based solely on Kluane people's arguments, regardless of how well they understood these arguments or how personally sympathetic they might have been. Biologists have to be able to justify (with scientific evidence) the positions they take on wildlife management. They must be able to answer the criticisms of other biologists employed by those with competing political interests. For them to take a position that they could not defend in this way would be viewed as irresponsible. Outfitters and others could then have criticized them for being biased and unscientific, and they would have been unable to defend themselves against 
these charges. Their reputation as scientists would have been damaged, and they might even have lost their jobs. And all of this would have been for naught; considering the political power wielded by outfitters in the territory, the government could not have implemented a hunting ban (or quota hunt) without incontrovertible scientific proof that the sheep population had once been as high as Kluane elders and hunters maintained. (It would have been difficult enough even with such proof.) In the absence of scientific evidence, supporting Kluane people's position regarding the past population size of the Ruby Range sheep population simply was not an option for biologists on the RRSSC. Yet this is precisely what they would have had to do if knowledge-integration were to succeed.

In the case of the RRSSC, the committee's failure to successfully integrate knowledge artifacts indicates more than a simple lack of trust between committee members. Indeed, the fact that the only instance of knowledgeintegration in the whole RRSSC process occurred between an outfitter and biologists is quite significant; and this significance was not lost on First Nation people. As we have seen, the integration of biologist and outfitter data that occurred in the case of the missing sheep was far from straightforward; it required a certain amount of creative interpretation to overcome the incomparability of the two counts. The fact that integration occurred in spite of these difficulties not only indicates that the outfitter and biologists trusted one another's motives and methods enough to work together to overcome these technical difficulties, but also highlights the political dimensions of knowledgeintegration. Biologists had accepted the outfitter's numbers at face value and were willing to base their actions (or non-action, in this case) on them without requiring additional proof, despite the fact that those numbers differed radically from their own. Kluane people felt that by doing this, biologists were extending to the outfitter a degree of trust that they had resolutely refused to extend to First Nation people.

By this time in the RRSSC process, some Kluane people had already begun to suspect that their position regarding sheep was being dismissed on political or racial rather than on intellectual grounds. When they saw that biologists were willing to trust the outfitter, whose economic interests gave him a clear motive for fabricating the results of his sheep count, and yet seemingly refused to trust the word of some of the most respected people in their community, they felt that their suspicions had been confirmed. In addition, the fact that biologists and outfitters could come to such an agreement without the consent, or even the involvement, of KFN illustrates the differences in power that existed between committee members.

Outfitters and First Nation people are unlikely to trust one another with very detailed information about their sheep sightings, so it is not surprising that biologists and outfitters did not invite KFN to participate in these discussions. However, the fact that Kluane people were also denied the opportunity to question the validity and use of the outfitter's knowledge, especially considering the obvious motive for fabricating his results, clearly illustrates the political dimensions of the incident. It is almost inconceivable, for example, that First Nation people could have excluded biologists and their knowledge from the process (as they themselves had been excluded) and still have effectively explained away such a dramatic change in the sheep population. Yet, biologists were able to use outfitter data in this way because there were no significant political obstacles preventing them from doing so (as there were to the use of First Nation people's testimony). The case of the missing sheep, perhaps more than any other single incident, caused Kluane people to lose confidence in the RRSSC process.

\section{CONCLUSION: REEVALUATING THE CO-MANAGEMENT SUCCESS STORY}

What was the ultimate outcome of the RRSSC process? Did it work, or was it a failure? The opinions of RRSSC members differed significantly on this question. Most biologists and government officials involved in the RRSSC were enthusiastic about the process. Some considered it successful enough to cite it as a model for future comanagement efforts. Yet most of the KFN members involved in the RRSSC process felt that it had been an utter failure. On what basis did different RRSSC members make these judgments?

The RRSSC mandate was to make recommendations to the Yukon Fish and Wildlife Management Board regarding the management of Ruby Range sheep. To a large extent, committee members judged the success of the process by assessing these recommendations. A quick comparison of these recommendations with the different positions on sheep management brought to the table by various groups of RRSSC members provides an indication of how RRSSC members could have viewed the process so differently (RRSSC, 1997). Of the 24 recommendations generated by the RRSSC, 12 dealt with the basically noncontentious issues of harassment, access, education, and predation. An additional six recommendations dealt specifically with how and when to conduct future scientific research. Five recommendations dealt with the contentious issue of hunting, and these were more consistent with the views of biologists and outfitters than with those of First Nation people. They called for voluntary efforts by all parties (as opposed to the imposition of a quota) to limit their combined kill to a maximum of $2 \%$ of the total population. If after two years, however, RRSSC members were to decide that voluntary compliance was not working, the RRSSC was to reexamine the issue and "recommend appropriate allocations" (RRSSC, 1997:8).

This may at first glance seem to be an equitable compromise between First Nation people's desire for an outright ban on sheep hunting and the belief by outfitters and biologists that no hunting restrictions were necessary. If 
we look at how this $2 \%$ was allocated, however, another picture emerges. Outfitters had agreed to limit their kill to $2 \%$ of the population, while resident hunters were requested to cease hunting sheep, and First Nation hunters were expected not to resume hunting in the area. Thus, "voluntary compliance" meant that outfitters got all the sheep. One other hunting recommendation requested that all parties "...should stop all hunting of ewes..." (RRSSC, 1997). This was clearly aimed at First Nation hunters, since ewe hunting is illegal for non-First Nation hunters; furthermore, the wording implied that First Nation people had been hunting sheep (specifically ewes) in recent years despite their explicit claims to the contrary throughout the process. One last recommendation dealt with the issue of traditional knowledge generally, but it had been so watered down that First Nation people felt it to be useless.

In the end, not even these limited recommendations were implemented. As of spring 1998, only a single one of them had been acted upon, and this was a recommendation to restrict ATV use in part of the Ruby Range, an initiative that had already been under consideration before the RRSSC process began. RRSSC members had agreed to limit sheep hunting in the area voluntarily, but even this agreement unraveled when it became known that one outfitter had killed 17 sheep during the 1997 season despite his promise to limit himself to 12 (which was $2 \%$ of the total population).

The fact that some RRSSC members considered the process a success despite these apparent failures indicates that different members judged the process by very different criteria. Most biologists felt at the start that the Yukon Minister of Renewable Resources was unlikely to limit sheep hunting in the area regardless of RRSSC recommendations. In fact, several biologists told me they feel quite frustrated by the fact that political criteria tend to outweigh scientific criteria in decision making for wildlife management throughout the territory. One biologist told me that he and other biologists viewed the RRSSC more as an effort to reduce hostility between outfitters and the Kluane First Nation than as a major management initiative, and several of them said they felt that it had been something of a victory just to get the different interest groups to sit down together in a room and speak to one another in a civil manner. They felt that the relationships that committee members had built with one another and the frank discussion of different views had been very positive developments. And the process had, after all, achieved its goal of developing a set of consensus-based management recommendations. Kluane people, however, based their assessment of the process solely on its results for sheep management. They had called the November 1995 meeting because of their concerns about Ruby Range sheep; and in three years, despite all the talk, nothing whatsoever had changed. When it became known that the outfitter had completely disregarded the commitments he made to the RRSSC, the few Kluane people who still had any hope for the process decided it had been more about appeasing KFN than a real effort to jointly manage sheep. They wrote it off as a complete waste of their time and resources.

Members of the RRSSC had very different ways of knowing and talking about sheep, but over and over again the methods and interpretations of biologists and outfitters won out over those of First Nation people. This was due not so much to the personalities of individual committee members as to the nature of the RRSSC process itself and of bureaucratic wildlife management more generally. Since the RRSSC process was created within the context of (and inserted into) existing systems of state resource management, biologists had no choice but to undervalue the artifacts of TEK vis-à-vis those of biology. This is because, given the politics of wildlife management in the territory, decisions simply cannot be made on the basis of TEK alone; biologists cannot accept TEK as a valid basis for action in its own right without undermining their own positions within the management system.

Despite the rhetoric of First Nation empowerment that surrounds the project of co-management and knowledgeintegration, the RRSSC process has, if anything, increased the power of Yukon government biologists vis-à-vis Kluane people over the management of Ruby Range sheep. Not only have biologists retained de facto control over sheep management in the area, but their participation in the RRSSC process enables them to forestall First Nation criticisms on the grounds that they are now engaging in cooperative management. And, because biologists now possess codified versions of Kluane elders' and hunters' knowledge about sheep, it is no longer even necessary for them to include actual First Nation elders and hunters in the process of "incorporating traditional knowledge into the management process." In effect, then, co-management and knowledge-integration - at least in the case of the RRSSC have served to further legitimate Yukon government biologists' control over sheep management rather than to grant Kluane people a measure of control over local wildlife.

Some members of the RRSSC disagree with this characterization of the process. Others wholeheartedly agree with it. Indeed, depending upon whom one talks to, one will hear either a scathing indictment of the RRSSC process or yet another co-management success story. By criticizing the RRSSC - and, by extension, all efforts at co-management-I have no wish to imply that every single attempt at co-management throughout the North to date has been an abject failure. The case of the RRSSC, however, serves as a warning that we need to be far more critical in our assessments of co-management. Co-management in its very conception is an exceedingly complex set of cross-cultural negotiations. In the process, even supposedly agreed-upon meanings are contested at multiple levels. To understand how well a particular effort at comanagement has worked (or even what "worked" means) is as difficult as understanding the cultural nuances of the negotiations themselves.

Some otherwise sympathetic readers will no doubt be frustrated that I offer no practical or constructive solutions 
to the problems with co-management that I have identified. While I believe that there are solutions to these problems, those solutions-like the problems themselvesare political rather than technical in nature. For example, I have suggested elsewhere (Nadasdy, 1999) that one possible solution to the political problems of co-management might be to devolve full decision-making power over wildlife (as opposed to merely the power to make recommendations) to local First Nations. Solutions of this sort are, for political reasons, unlikely to be implemented or even recognized as potential solutions, but this does not invalidate them; it only serves to highlight the inherently political nature of wildlife management. Indeed, rather than challenging the larger political context in which wildlife management occurs, co-management regimes have merely been inserted into existing structures of bureaucratic wildlife management - the very same structures that are at the root of the problems I identify in this article (see Nadasdy, in press). And since co-management takes for granted the wider political context of wildlife management, solutions to the political problems I identify cannot be found in the realm of co-management at all. Those involved in co-management, after all, are in the business of solving management problems, such as the problem of the missing sheep, not of addressing political issues, such as who should have jurisdiction over wildlife in the Yukon. Since it is not simply a matter of "fixing" co-management (e.g., by improving techniques for gathering information or integrating knowledge or by tweaking the structures of particular co-management regimes) but of restructuring the very institutions, practices, and underlying assumptions of wildlife management itself, the kinds of solutions I would offer are not likely to strike most readersespecially those actually engaged in efforts to co-manage resources-as particularly practical or constructive.

\section{ACKNOWLEDGEMENTS}

I would like to thank the people of Burwash Landing, Yukon, without whose generous help and support this paper could never have been written. I am similarly indebted to all the members of the Ruby Range Sheep Steering Committee, who allowed me to participate in RRSSC meetings and other aspects of the sheep management process. Versions of this paper were presented at a workshop entitled "Local Knowledge, Natural Resources, and Community Survival: Charting a Way Forward" in Prince Rupert, British Columbia, on 2 February 2002 and at the 9th International Conference on Hunting and Gathering Societies in Edinburgh, Scotland, on 9 September 2002; the paper benefited from discussion and comments received at each. In addition, Sara Berry, Elizabeth Ferry, Katherine Verdery, Marina Welker, and three anonymous reviewers provided helpful comments on early drafts of the paper. The research upon which this paper is based was made possible by grants from the National Science Foundation, Office of Polar Programs-Division of Arctic Social Science, the Wenner-Gren Foundation for Anthropological Research, and a Canadian Studies Graduate Fellowship.

\section{REFERENCES}

ARTHURS, D. 1995. Archaeological surveys in the Donjek, Jarvis, Kaskawulsh, and Alsek Valleys, Kluane Park Reserve 1993. Winnipeg: Archaeological Field Services, Parks Canada, Department of Canadian Heritage.

BRODY, H. 1982. Maps and dreams. New York: Pantheon Books. COUNCIL FOR YUKON INDIANS. 1993. Umbrella final agreement between the government of Canada, the Council for Yukon Indians, and the Government of the Yukon. Ottawa: Minister of Indian Affairs and Northern Development.

CRUIKSHANK, J. 1998. The social life of stories: Narrative and knowledge in the Yukon Territory. Lincoln: University of Nebraska Press.

FERGUSON, M., and MESSIER, F. 1997. Collection and analysis of traditional ecological knowledge about a population of Arctic tundra caribou. Arctic 50(1):17-28.

FIENUP-RIORDAN, A. 1998. Yaqulget Qaillun Pilartat (What the Birds Do): Yup'ik Eskimo understanding of geese and those who study them. Arctic 52(1):1-22.

FREEMAN, M.M.R., and CARBYN, L.N., eds. 1988. Traditional knowledge and renewable resource management in northern regions. Edmonton: Boreal Institute for Northern Studies.

HOEFS, M. 1981. The Dall sheep population of Sheep Mountain/ Kluane National Park: Review of natural history, assessment of population dynamics, and recommendations for management. Parks Canada. Unpubl. ms. Available at the Yukon Department of Renewable Resources, Whitehorse, Yukon Y1A 2 C6.

INGLIS, J., ed. 1993. Traditional ecological knowledge: Concepts and cases. Ottawa: International Program on Traditional Ecological Knowledge.

JOHANNES, R., ed. 1989. Traditional ecological knowledge: A collection of essays. Gland, Switzerland: IUCN, World Conservation Union.

KFN AND YTG (KLUANE FIRST NATION AND YUKON TERRITORIAL GOVERNMENT). 1996. Ruby and Nisling Range wildlife meeting, November 8, 1995. Report prepared for the Ruby Range Sheep Steering Committee by the KFN and YTG. Available from Yukon Department of Environment, Fish and Wildlife Branch, 10 Burns Road, Whitehorse, Yukon Y1A 4 Y9.

McCANDLESS, R. 1985. Yukon wildlife: A social history. Edmonton: University of Alberta Press.

. n.d. Trophies or meat: Yukon game management. Unpubl. ms. Available at the Yukon Archives, Government of Yukon, Box 2703, Whitehorse, Yukon Y1A 2C6.

McCLELLAN, C. 1975. My old people say: An ethnographic survey of southern Yukon Territory. Publications in Ethnology No. 6. Ottawa: National Museum of Man.

NADASDY, P. 1999. The politics of TEK: Power and the "integration" of knowledge. Arctic Anthropology 36(1-2): $1-18$.

- 2003. Hunters and bureaucrats: Power, knowledge, and aboriginal-state relations in the southwest Yukon. Vancouver: UBC Press.

- in press. The anti-politics of TEK: The institutionalization of co-management discourse and practice. Anthropologica 45(2). 
NELSON, R.K. 1983. Make prayers to the raven: A Koyukon view of the northern forest. Chicago: University of Chicago Press.

ROBERTS, K., ed. 1996. Circumpolar aboriginal people and comanagement practice: Current issues in co-management and environmental assessment. Proceedings of a conference held 20-24 November 1995 in Inuvik, NWT. Calgary, Alberta: The Arctic Institute of North America.

RRSSC (RUBY RANGE SHEEP STEERING COMMITTEE). 1995. Minutes from the December 4 meeting of the Ruby Range Sheep Steering Committee, prepared by Geraldine Pope. Available at the Yukon Department of Renewable Resources, Whitehorse, Yukon Y1A 2C6.

. 1996a. Draft Recommendations from the Ruby Range Sheep Steering Committee to the Yukon Fish and Wildlife Management Board. April 1996. Copy in possession of the author.

1996b. Minutes from the January 10-11 Meeting of the Ruby Range Sheep Steering Committee, prepared by Paul
Nadasdy. Available at the Yukon Department of Renewable Resources, Whitehorse, Yukon Y1A 2C6.

. 1997. Final Recommendations from the Ruby Range Sheep Steering Committee to the Yukon Fish and Wildlife Management Board on March 6, 1997. Available at the Yukon Department of Renewable Resources, Whitehorse, Yukon Y1A 2 C6.

URQUHART, D., ed. 2001. Conference Summary. Proceedings of the Two Eyes: One Vision Conference, held 1-3 April 1998 in Whitehorse, Yukon. Whitehorse: Yukon Fish and Wildlife Management Board.

WILLIAMS, N., and HUNN, E., eds. 1982. Resource managers: North American and Australian hunter-gatherers. AAAS Selected Symposium 67. Boulder, Colorado: Westview Press.

YTG (YUKON TERRITORIAL GOVERNMENT). 1997. Information packet provided to the Ruby Range Sheep Steering Committee by the Yukon Territorial Government, Department of Renewable Resources, on January 7, 1997. Compiled by Jean Carey. Copy in possession of the author. 